\title{
Coverage of sedition charges against JNU students in The Hindu \& The Times of India
}

\author{
Sobhika V ${ }^{1}$, Sikha N. ${ }^{2}$ \\ 1 (Sub-Editor, The Eco Pages, Green magazine, Kerala) \\ 2 (Guest Lecturer, Department of Journalism \& Mass Communication, University of Calicut, Kerala, India)
}

\begin{abstract}
Media have always played a vital role in positioning of a story since its origin. The coverage of a news item and its positioning in the newspaper will decide the significance of the story. If a newspaper gives more importance to a news item, then there will be an agenda behind it. These agenda will make readers to think the particular story as a crucial one at the time. The study examines the newspaper coverage of JNU issue of two national dailies. The researchers try to examine the coverage of the news by analysing its position in the newspapers. This study attempts to examine the coverage of the JNU controversy by analysing the two national dailies, The Hindu and The Times of India. Method of the study was content analysis. Qualitative and quantitative methods have been used to examine the reports. The study also discusses the frames used in the reports by the newspapers. The study period was from $10^{\text {th }}$ February 2016 to $3^{\text {rd }}$ March 2016. The samples were taken and measured by the researchers. The news stories, photographs, editorials, space, quotations etc. have been measured.
\end{abstract}

Keywords: JNU controversy, newspaper coverage, positioning, agenda setting, framing, The Hindu, The Times of India

\section{INTRODUCTION}

The prime responsibility of a newspaper is to inform people about the latest events. Journalists gather news and information daily that may directly or indirectly relate to the human life. Every segment including political, administrative, environment, education, and entertainment comes under the news title. Events that affect people may absorb more space in the newspaper. The content will be large and authentic. It shall carry the minute details of the story. The mass media always viewed as a powerful tool to influence people's view and observation. In this study, the researchers try to find out how did the national dailies, The Hindu and The Times of India reported the Jawaharlal Nehru University controversy of sedition. The issue has risen because of the cultural event happened at the University campus on February $9^{\text {th }}$ evening. Both the newspapers have played a crucial role in covering the issue.

\section{I.1 Agenda setting}

Making of a story has some strategies. Every news organizations will have its own strategies and styles regarding the story. By comparing the salience of issues in news content with the public's perceptions of the most important election issue McCombs and Shaw were able to determine the degree to which media determines public opinion. Since the 1968 study, published in a 1972 edition of Public Opinion Quarterly, more than 400 studies have been published on the agenda setting function of the mass media and the theory continues to be regarded as relevant. Each and every media organizations will have a particular agenda setting theory. The organization frames news stories, articles, columns, advertisements and various other materials according to this agenda. There will be agendas for every organization, political parties and government. They moves by this agenda and without it, there won't be any coordination.

\section{I.2 Theoretical Framework}

Framing is a process of presenting a narrative to a target audience that promotes a desired interpretation of perceived reality by highlighting some aspects or issues while disregarding others and making connections among them (Entman, 2007).The process by which the media place reality into frame; and the study of the process of framing is at the core of media analysis, hence the length of this entry. Framing constitutes a narrative device. What is not on the page of a newspaper is 'out of frame'; what does not appear to put in the frame. Time, then the shortness of it- is an importing deciding factor. (James Watson, 2003). The framing theory was put forwarded by Erving Goffman, in his study, Frame Analysis: an Essay on the organization of Experience. He put forth that people interpret what is what is going on around their world through their primary framework. 
For Goffman, 'the frames are not consciously manufactured but are unconsciously adopted in the course of communicative processes’ (He, 2010).

\section{REVIEW OF LITERATURE}

Durga Ray, University of South Florida, in her article, "Frames in the U.S Print Media Coverage of the Kashmir conflict" (2004), examined the frames used by the U.S print media- The New York Times, The Washington Post and Los Angeles Times- in their coverage of the Kashmir conflict and the parties involved in it from 1989 to 2003. The study divided the fifteen year coverage into four phases - 1989-1990, 1991-1998, 19992001 and 2002-2003. The study has found that in the first two phases, the conflict was described as a violent Kashmiri separatist movement and depicting it is ongoing violent conflict between India and Pakistan.

"Framing and Coverage of same sex marriage in U.S Newspapers", (2010), published in Howard Journal of Communications, by Xigen Li, City University of Hong Kong and Xudong Liu, Southern Illinois University Carbondale, USA, examined fairness and balance in the coverage of same sex marriage by five U.S newspapers and how source use, newspaper working context, and media frames affect fairness and balance of the coverage. Content analysis has been used for the findings. By analyzing 209 stories they found that overall coverage of same sex marriage was fair and balanced and stories framed as episodic.

Usharani Narayana, Department of Communication and Journalism, University of Mysore and Priti Kapur, Head of the Department of Photography and Photojournalism at the Chamarajendra, Academy of Visual Arts, Mysore, examined how the media has treated Muslims, the largest minority group in India in their study entitled "Indian Media Framing of the image of Muslims; An Analysis of News Coverage of Muslims in English Newspapers of India" (2011), published in Media Asia volume: 38. The researchers used an analytical technique of framing approach. They have taken five mainstream national newspapers namely The Statesman, the Indian Express, The Hindu, the Hindustan Times and The Times of India. The news reports and other editorial content pertaining to Muslims that were published between 2001 and 2006 were selected through Lexis-Nexus database.

"Unseen and Unheard-how Dalits are represented in three Indian newspapers" (2012) by Joanna Wahlstedt of University of Sodertorn, Department of Communication Media and IT, examined how the Dalits are represented in three newspapers: The Times of India, The Hindu and Indian Express. It focuses on how do journalists find their reporting about Dalits by using the theories: development journalism, the agenda setting theory and theory about minorities in media. The quantitative content analysis was done in Delhi during 17 days. 98 articles that mentioned Dalits were found and coded. The qualitative method used respondent research. And the results show that Dalits are mentioned quiet often in the newspapers, but the main subject is almost never Dalits and their situation in society.

The study titled "Representation of Violence against women in Indian print media: A comparative analysis" (2012) by Rupsyar Das, University of Calcutta, aimed at investigating print news discourses on an act of violence perpetrated on women in India, which evoked a nation-wide non-violent protest, popularly known as 'The Pink Chaddi' campaign, 2009. The analysis has been done between national and local newspapers. The advanced computer-assisted qualitative data analysis software has been used for the content analysis.

"Newspaper framing of the Kudamkulam Nuclear power project in Tamil Nadu" (2016) by I. Arul Aram, G.C. Prem Nivas and G.P. Ramya, Anna University, Chennai, analysed the framing of the Kudamkulam nuclear power project issue in two major newspapers: The Hindu and The Times of India. The research has found that episodic framing was used more in The Times of India than in The Hindu. Thematic framing was adopted by The Hindu than by The Times of India.

\section{OBJECTIVES OF THE STUDY}

- To find out the differences in coverage of the story of JNU controversy by the selected newspapers.

- To find out how the selected newspapers frame the JNU issue

\section{METHODOLOGY}

Qualitative and quantitative content analyses are used to find out the priorities and significance of the newspapers to the given issue. Qualitative and quantitative content analysis is carried out to find out the coverage of JNU controversy in The Hindu and The Times of India. The qualitative content analysis will help to understand the style and significance of the coverage regarding the issue. And the quantitative content analysis will help to count the number of stories, photographs; space and editorial have given to the issue by the both national dailies. The study focus deeply analyzing the content of news articles, editorial page, columns and features, front page columns and photographs about the topic. 


\section{SAMPLING PROCEDURE}

In this study, two newspapers are selected to observe the qualitative and quantitative content analysis regarding the JNU controversy of sedition which appeared in the two national dailies The Hindu and The Times of India. The study period was from February $10^{\text {th }} 2016$ to March $3^{\text {rd }} 2016$. This period was decisively selected since it was during that time the controversy has occurred and got a wide media coverage

\section{RESULTS}

The study analyses the newspaper coverage of JNU controversy by the two national dailies The Hindu and The Times of India. The study focuses on how much importance the newspapers have given to the issue. The study period was from February $10^{\text {th }} 2016$ to March $3^{\text {rd }} 2016$.

\section{VI.1 Space allocation by segments}

The study focuses on the newspaper coverage of the issue in a theoretical way. How much space has been allotted for the issue, how the story has been framed etc. are analysed.

Table 1: Space allocation of stories

\begin{tabular}{|l|l|l|}
\hline Space & The Hindu & The Times of India \\
\hline Front page & 35911.8 column c.m & 48717.83 column c.m \\
\hline Editorial page & 43656.41 column c.m & 26861.44 column c.m \\
\hline Inner page & 1502614.87 column c.m & 531837.67 column c.m \\
\hline Photograph & 93934.08 column c.m & 13387.08 column c.m \\
\hline All stories & 1582183.08 column c.m & 748766.7 column c.m \\
\hline
\end{tabular}

The Hindu has given more space to the controversy in editorial page. It has given a total space of 43656.41 column c.ms to the JNU row. The Times of India's editorial page occupied a total of 26861.44 column c.ms to the issue. The more news coverage appeared in the inner pages of the newspapers. The Hindu has given a total of 1502614.87 column c.ms on the controversy. And The Times of India allotted a total of 531837.67 column c.ms. In the case of photographs, The Hindu has given a total of 93934.08 column c.ms to the JNU topic. At the same time, The Times of India has given a total of 13387.08 column c.ms to the subject.

Table 2: Total space allotted to the news items in The Hindu \& The Times of India

\begin{tabular}{|l|l|l|l|l|}
\hline Space & $\begin{array}{l}\text { \% of The } \\
\text { Hindu }\end{array}$ & $\begin{array}{l}\text { Total news space of } \\
\text { The Hindu }\end{array}$ & $\begin{array}{l}\text { \% of The } \\
\text { Times of India }\end{array}$ & $\begin{array}{l}\text { Total news space of } \\
\text { The Times of India }\end{array}$ \\
\hline Front page & $12.58 \%$ & $1907.5 \mathrm{c} . \mathrm{ms}$ & $12.2 \%$ & $1500 \mathrm{c} . \mathrm{ms}$ \\
\hline $\begin{array}{l}\text { Editorial } \\
\text { page }\end{array}$ & $36 \%$ & $1700 \mathrm{c} . \mathrm{ms}$ & $19 \%$ & $800 \mathrm{c} . \mathrm{ms}$ \\
\hline Inner page & $20 \%$ & $4500 \mathrm{c} . \mathrm{ms}$ & $12.12 \%$ & $4100 \mathrm{c} . \mathrm{ms}$ \\
\hline Photograph & $4.12 \%$ & $1700 \mathrm{c} . \mathrm{ms}$ & $2.35 \%$ & $1700 \mathrm{c} . \mathrm{ms}$ \\
\hline Total \% & $18.18 \%$ & $9807.5 \mathrm{c} . \mathrm{ms}$ & $11.41 \%$ & $8100 \mathrm{c} . \mathrm{ms}$ \\
\hline
\end{tabular}

The Times of India however gave $12.2 \%$ coverage to the issue in the front page. It took a total of $19 \%$ in the editorial page. The inner page coverage of the paper was $12.12 \%$. In the case of photographs, a total of $2.35 \%$ has occupied by the newspaper. The grant total was $11.41 \%$.

\section{.VI.2 Space allocation for cartoons}

Not only the content and photographs tells the issue but also the cartoons. A well draw cartoon will tell a story completely without any confusion.

Table 3: Total Space allocation to cartoon

\begin{tabular}{|l|l|l|}
\hline Total & The Hindu & The Times of India \\
\hline No. & 4 & 7 \\
\hline Space & 2670.81 column c.m & 5330.87 column c.m \\
\hline
\end{tabular}

The Hindu published 4 cartoons during the time with a total of 2670.81 column c.ms. And The Times of India has published 7 cartoons during the time. It allotted a total of 5330.87 column c.ms for cartoons. 


\section{VI.3 News bais}

The JNU event took a wide turn in the politics of the country. The newspaper reports contributed to it. It reported in favour of the government and the JJNU students. And sometimes it took a neutral decision.

Table 4: News bias of The Hindu

\begin{tabular}{|c|c|c|}
\hline $\begin{array}{l}\text { Exclusively in favour of } \\
\text { the government }\end{array}$ & $\begin{array}{l}\text { Neutral or } \\
\text { equally balanced }\end{array}$ & $\begin{array}{l}\text { Exclusively in favour of } \\
\text { the students of JNU }\end{array}$ \\
\hline 0 & 75 & 30 \\
\hline
\end{tabular}

It gave 30 news stories in favour of the institution, while they also published 75 stories in neutral.

Table 5: News bias of The Times of India

\begin{tabular}{|c|c|c|}
\hline $\begin{array}{l}\text { Exclusively in favour of } \\
\text { the government }\end{array}$ & $\begin{array}{l}\text { Neutral or } \\
\text { equally balanced }\end{array}$ & $\begin{array}{l}\text { Exclusively in favour of } \\
\text { the students of JNU }\end{array}$ \\
\hline 17 & 42 & 6 \\
\hline
\end{tabular}

The Times of India reported 17 stories in favour of the administration. And it gave 6 stories in support of the JNU students. They published 42 equally balanced stories of the event.

\section{VI.4 Visual representations}

The visual representations of the news stories also are very important. It helps to make aware of the situation to its very extent.

Table 6: Visual representations of the stories of The Hindu

\begin{tabular}{|l|l|l|l|}
\hline $\begin{array}{l}\text { Single } \\
\text { Colour }\end{array}$ & $\begin{array}{l}\text { Single Black \& } \\
\text { White }\end{array}$ & $\begin{array}{l}\text { Group } \\
\text { Colour }\end{array}$ & $\begin{array}{l}\text { Group Black \& } \\
\text { White }\end{array}$ \\
\hline 1 & 7 & 4 & 23 \\
\hline
\end{tabular}

The Hindu has given a total of 35 photographs to the event. The photographs include a single colour photo that only shows the person. 7 single black and white photos, 4 group colour photos and 23 black and white group photos. By analysing these photos the researcher came to know about the intensity of the JNU issue, that it got throughout the nation.

Table 7: Visual representations of the stories of The Times of India

\begin{tabular}{|l|l|l|l|}
\hline $\begin{array}{l}\text { Single } \\
\text { Colour }\end{array}$ & $\begin{array}{l}\text { Single Black \& } \\
\text { White }\end{array}$ & $\begin{array}{l}\text { Group } \\
\text { Colour }\end{array}$ & $\begin{array}{l}\text { Group Black \& } \\
\text { White }\end{array}$ \\
\hline 2 & 1 & 8 & 8 \\
\hline
\end{tabular}

TOI has published 2 single colour photos, a single black and white, 8 group colour photos and 8 black and white group photos.

\section{VI.5 Quotations cited}

For every news story, there will be a quotation by any eminent personality that may lead to another topic for discussion. In this controversy, Congress Vice President Mr. Rahul Gandhi, Delhi Chief Minister Mr. Arvind Kejriwal, BJP leader Amit Shah and many other leaders has expressed their opinions and viewpoints. The Hindu published numerous source quotations. It published almost 18 source quotations during the period. It included various opinions of the leaders regarding the event and it also quoted Mr. Kanhaiya Kumar, the JNUSU leader.

Table 8: Number of quotations in The Hindu and The Times of India

\begin{tabular}{|l|l|}
\hline The Hindu & The Times of India \\
\hline 18 & 1 \\
\hline
\end{tabular}




\section{VI.6 Headline Analysis}

Headings are the next significant area of research. The font size of the heading will show the importance of the news story. The importance of the story increases when the headline catches bold font.

Table 9: Headline analysis of The Hindu

\begin{tabular}{|c|c|c|l|}
\hline Single line bold & Double line bold & Three line bold & Normal \\
\hline 50 & 30 & 5 & 20 \\
\hline
\end{tabular}

The Hindu has given 50 single lined bold heading of the controversy. It also gave 30 double lined, 5 three lined bold heading and 20 normal heading of the issue. The research had gone through the analysis of these headings. The headings portrayed the incident rigorous.

Table 10: Headline analysis of The Times of India

\begin{tabular}{|c|c|c|l|}
\hline Single line bold & Double line bold & Three line bold & Normal \\
\hline 12 & 25 & 18 & 10 \\
\hline
\end{tabular}

The Times of India has published 12 single lined bold news headings. It also published 25 double lined, 18 three lined bold headings and 10 normal headings. The single line bold heading mostly came in the front page of the newspaper. It also gave bold headings in the editorial page and inner pages.

\section{VI.7 Qualitative Analysis}

The episodic framing focuses on individual case studies and distinct events. The Times of India have covered the issue in episodic frame. Episodic framing covers things in a different way. The Times of India focused more on Mr. Kanhaiya Kumar, the JNUSU leader. The paper clearly states that the paper is against the anti-national activities; hence they are not supporting the JNU campus students. But the entering of police into the campus and putting sedition charges over the students was unacceptable by them. The Times of India holds the opinion of the government in some stories. They have given more importance to the government sided news. Government centric news got more space on the paper. It also published neutral stories. The attack of the lawyers at Patiala House Court complex was well reported by the paper. The heading 'JNU student leader thrashed in court' intensifies the depth of the story. The word 'thrashed' indicates how Mr. Kanhaiya Kumar was beaten up in the court complex. After the violence, there occurred many dramatic moments. Each day the significance of the issue has increased.

The political leaders had started a war of words over the issue. The term 'anti-national' had struck in everybody's mind. It was the matter of right to freedom of speech. The question that risen after the issue is, 'if the JNU students are 'anti-nationals', then what is nationalism?' The media had discussed over the topic seriously. The sedition charge over the student leader was unacceptable for the academicians and many logical thinkers. They questioned the decision of the central government. The other Universities had also step forward in protest over the arrest of Mr. Kumar. The newspapers have excellently covered the student agitation and protest in the Delhi streets. Discrimination based on caste is the biggest thing that made the issue more crucial. The student's union leader of JNU, Mr. Kanhaiya Kumar belongs to a Dalit family from Bihar. The issue was revolved around the commemoration of Afzal Guru, but soon, the plot has diverted to caste and Dalit issue. Hence, the case against them was allegedly raising anti-national slogans. The supporters of Mr. Kanhaiya Kumar argued that, he was being victimised of being a Dalit. Both the newspapers have contributed their maximum to raise the caste issue in the society. Debates and discussions held based on the issue for days. The student's wing has used the card of caste in popularising the issue well.

\section{DISCUSSION}

The media always played a crucial role in shaping the public opinion. The public response is highly influenced by the news dispersed through the mainstream media such as newspapers. People find more comfort in gathering news from newspapers. Therefore, the newspapers should publish news based on the truth, not from their political ideology. It will create ambiguity among the public and they will mould their perspective regarding the newspaper content. The study had focused on the coverage of JNU issue of sedition by the prominent English national dailies The Hindu and The Times of India. It also analysed how the newspapers had framed the story through using framing theories. The issue got a wide coverage in all the national as well as regional dailies. It is the media that made the issue more prominent by covering all its aspects. The newspapers had tried to its best cover the all minute details of the issue. The papers had published stories in favour of the students and the government. The media had played a vital role in propagating the issue. Without the media, the issue would not have enough significance. Hence the study has examined all the aspects of the JNU issue. It has discussed the quantitative and qualitative analysis of the content. 
The present study found that The Hindu had allotted more space to the issue than The Times of India. The Hindu has used thematic model of framing whereas The Times of India had used the episodic model of framing. The Hindu has covered the news in favour of the students. At the same time they have also published news in neutral. The Times of India hence gave more importance to the persons. While analysing the news stories, the researcher found that The Hindu has a supported the students agitation and protest movements. The Times of India, the most circulated daily of the nation, opposed the 'anti-national' activities that occurred in the campus. The photographs of both the newspapers had revealed the real situation of the time. The intensity of Patiala court complex attack over the student leader was portrayed by the photographers. The photographs tell the truth. The study has analysed the depth of the photographs.

\section{CONCLUSION}

The analysis of the content of the newspaper has revealed that The Hindu has allotted more space to the JNU issue than The Times of India. The caste frame, political frame, student's politics frame, thematic frame and episodic frame has been used in the analysis of the JNU crisis. Study has some limitations too. The study examined only two newspapers namely The Hindu and The Times of India. Hence the assumption from this study cannot be applied to the entire daily press in India.The time period for content analysis was only limited to February $10^{\text {th }}$ to March $3^{\text {rd }}, 23$ days. The study was limited to content analysis of newspapers; therefore, the awareness of the news stories on the readers could not be analyzed. Lack of focus group interviews and Time constraint in elaborately examining the each news story appeared regarding the issue is also a limitation. Furthermore, for the study, it will be good to select more newspaper to understand the perspective concerning the issue. It will be better to select regional dailies and national dailies to study comparatively on the topic. The researcher had selected only one month period to study on the topic it will be good to select three month time period to study the issue. Then one will get the complete situation and agenda of the papers behind it.

It will be better to add focus group interview and opinion of the people regarding the topic. The study can be elaborate by adding more newspapers, theories and interviews etc. it will help to make the study more fruitful. Through the study, the researcher may understand the agenda of the media and how it portrays a sensational story.

\section{REFERENCES}

[1] A.Scheufele, D. (2009). Agenda setting, priming and Framing Revisited: Another look at Cognitive Effects of Political Communication. Mass Communication and Society, 1-21.

[2] An Analysis of Framing in British New media Representations of China and the Chinese. (2010). Creative Commons, 1-362.

[3] Benjamin, D. (2007). Framebyte Episodic VS Thematic stories. A Frameworks Institute, 1-3.

[4] Das, R. (2012). Representation of Violence against women in Indian Print media: A comparative Analysis. Global Media Journal, 1-24.

[5] Emma Waterson, S. W. (2013). Framing theory: towards a critical Imagination in Heritage studies. International Journal of Heeritage studies, 1-17.

[6] He, M. (2010). An Analysis of Framing n British News media representations of China and the Chinese. 25-29.

[7] I. Arul Aram, G. P. (2014). Newspaper Framing of the Kudamkulam Nuclear Power Project in Tamil Nadu. Media Asia, 1-4.

[8] Junling Gao, H. F. (2013). Newspaper coverage of HIV/AIDS in China from 2000-2010. AIDS Care, 1-6.

[9] Kark, M. (2013). Understanding Indain and Pakistani cultural Perspectives and analysing U.S News coverage of Mukhtar Mai and Jyoti Singh Pandey. 1-83.

[10] Maxwell E. McCombs, D. L. (2014). New Directions in Agenda setting Theory and Research. Mass Communication and Society, 1-23.

[11] Mundadan, K. (2004). Religion Tolereance and the Press: an Analysis of Socio-political factors in thee coverage of Religion Issues in the Indian Newspapers. 1-14.

[12] Ray, D. (2004). Frames in the U.S print Media coverage of the kashmir Conflict. Scholar Commons, 1121.

[13] Usharani Narayana, P. K. (n.d.). Indian Media Framing of the Image of Muslims: an Anlaysis of news coverage of Muslims in English newspapers of India. 1-10. 